\title{
SIMULATED SOFC EXHAUSTS AND THEIR FIXATION ON CHLORELLA VULGARIS: STUDY ON AFFECTING PARAMETERS
}

\author{
Davide Papurello 1,*, Maurizio Bressan 1, Daniela Bona 2, Giovanna Flaim ${ }^{3}$, Leonardo \\ Cerasino ${ }^{3}$ and Silvia Silvestri ${ }^{2}$ \\ ${ }^{1}$ Politecnico di Torino, DENERG, corso Duca degli Abruzzi 24, 10129 Torino, Italy \\ ${ }^{2}$ Technology Transfer Centre, Fondazione E. Mach, via E. Mach 1, 38010 San Michele a/A, Italy \\ ${ }^{3}$ Research and Innovation Centre, Fondazione E. Mach, via E. Mach 1, 38010 San Michele a/A, Italy
}

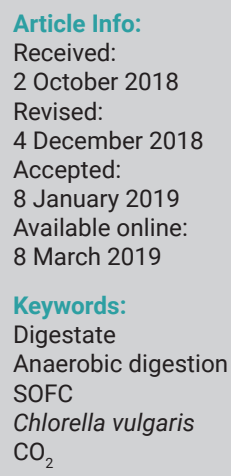

\begin{abstract}
To curtail greenhouse gas emissions local and distributed energy systems should be fed by renewable and high efficiency fuels. Anaerobic digestate of organic waste from biogas production can be adopted as a substrate, coupled to Solid Oxide Fuel Cell (SOFC) exhausts, for biomass culture. This biorefinery concept can be exploited towards the complete integration of a waste treatment plant. The work concern the preliminary tests assessed to identify the condition to obtain microalgal growth on dry digestate from anaerobic digestion of organic waste and $\mathrm{CO}_{2}$ remaining after power and heat production by fuel cells biofixation. The results of digestate pretreatment and dilution, inoculum: digestate ratio and $\mathrm{CO}_{2}$ supply system were reported. Each test was controlling operating temperature and light intensity using a common green alga, Chlorella vulgaris. Different tests were performed for testing digestate dilution (from 1:20 to 1:70) and for defining microalgal inoculum concentration (9\%, $20 \%$ and $32 \%$ ). All trials were performed at laboratory scale. The optimal digestate pretreatment and microalgal inoculum concentration was used for achieving $\mathrm{CO}_{2}$ biofixation in an experimental reactor $(15 \mathrm{~L})$. The best dilution for the digestate was found to be approximately 1:70 and inoculum percentage equal to $20 \%$.
\end{abstract}

\section{INTRODUCTION}

The distribution of high energy efficiency systems fed by renewable fuels is crucial for the future. Solid Oxide Fuel Cells (SOFC) are highly efficient energy systems that can be fed by renewable fuels (Choudhury, Chandra, \& Arora, 2013; Eveloy \& Gebreegziabher, 2019; Hagen, Rasmussen, \& Thydén, 2011; Kupecki et al., 2018; Andrea; Lanzini, Leone, \& Asinari, 2009; Papurello, Menichini, \& Lanzini, 2017; Saadabadi et al., 2019; Shiratori, ljichi, Oshima, \& Sasaki, 2010). Experimental results in this field, from laboratory scale to pilot plant systems are encouraging, considering the integration between the real networks and the intermittency of renewable sources (A. Lanzini, Ferrero, Papurello, \& Santarelli, 2017; Papurello, lafrate, Lanzini, \& Santarelli, 2017; Papurello \& Lanzini, 2017; Papurello, Lanzini, Leone, \& Santarelli, 2016; Papurello, Lanzini, Tognana, Silvestri, \& Santarelli, 2015; Papurello, Silvestri, Tomasi, Belcari, et al., 2016b; Papurello, Tomasi, Silvestri, Belcari, et al., 2016; Papurello, Tomasi, Silvestri, \& Santarelli, 2016). The ability to remove and to fix carbon dioxide from SOFC exhausts is also a crucial theme to be addressed for future development. Such benefits are related to the high purity of these exhausts, which does not require strong methods of cleaning, to avoid the pollutants interaction with the biological route for the algae growth (Santarelli, Briesemeister, Gandiglio, Herrmann, Kuczynski, Kupecki, Lanzini, Llovell, Papurello, Spliethoff, Swiatkowski, Torres-Sanglas, et al., 2017). Among several methods, carbon dioxide can be removed or separated from a gas flow with adsorption or absorption methods, or using membranes or biological systems (Rasi, 2009). Among biological methods, carbon dioxide can be fixed into new biomass through algae production (Molino, Nanna, Ding, Bikson, \& Braccio, 2013). A strongly connected benefit is the sink generation for the biogenic $\mathrm{CO}_{2}$ removal, with the biomass circular production approach. Microalgae can grow 10-50 times faster than terrestrial plants because they can fix captured solar energy as high-energy-density lipids (Ho, Kondo, Hasunuma, \& Chang, 2013). Also microalgae do not have roots, shoots, and leaves that represent energy sinks. During photosynthesis, $\mathrm{CO}_{2}$ is converted into sugars, inter alia, with the use of energy derived from ATP (adenosine triphosphate 5) and with the participation of the Rubisco-ribulose bisphosphate carboxylase oxygenase enzyme in the Calvin Cycle (Packer, 2009). Efficiency 
of microalgal photosynthesis can range from 3\% (Spirulina sp.) to $20 \%$ (Chlorella sp.). Moreover, because of their high concentration of cellular lipids, microalgae can be used as feedstock for biofuel production, such as biodiesel (Strange, Hastings, \& Wales, 2010). The use of microalgae is seen as a reasonable and efficient way of biofixation of $\mathrm{CO}_{2}$ (Benemann, 1997; Rosenberg, Mathias, Korth, Betenbaugh, \& Oyler, 2011). Biological methods of $\mathrm{CO}_{2}$ capture from gas exhausts are potentially useful and need to be evaluated. Few studies have treated the integration of microalgal production and SOFCs exhausts (Santarelli, Briesemeister, Gandiglio, Herrmann, Kuczynski, Kupecki, Lanzini, Llovell, Papurello, Spliethoff, Swiatkowski, Torres-sanglas, et al., 2017). The SOFCexhaust could employed to sustain microalgae growth due $\mathrm{CO}_{2}$ content expected in the range between (29-38.7\%vv) (Santarelli, Briesemeister, Gandiglio, Herrmann, Kuczynski, Kupecki, Lanzini, Llovell, Papurello, Spliethoff, Swiatkowski, Torres-Sanglas, et al., 2017). The SOFC exhausts could better than other exhaust due the biogas was cleaned by the some important contaminants before feeding the stack (Papurello, Schuhfried, et al., 2015; Papurello, Silvestri, Tomasi, Belcari, et al., 2016a; Papurello, Tognana, et al., 2015; Papurello, Tomasi, \& Silvestri, 2018; Papurello, Tomasi, Silvestri, Belcari, et al., 2016). Considering that the SOFC exhaust composition is now under study, the aim of this work is to perform at lab scale a system suitable to capture $\mathrm{CO}_{2}$, simulating the SOFC exhaust. The exhausts originated from a SOFC system fed by biogas and the digestate were produced by the anaerobic digestion of organic fraction of municipal solid waste (OFMSW) in dry mesophilic anaerobic reactor [20]. The experimental goal was to investigate the main parameters affecting microalgal production using diluted digestate and simulated SOFC exhaust. The parameters considered were the best digestate dilution to avoid growth inhibition phenomena, the microalgal inoculum concentration, and the effect of $\mathrm{CO}_{2}$ supply. These preliminary results on the experimental condition needed to obtain a good $\mathrm{CO}_{2}$ fixation rate that will used in the future experimental tests with pilot scale reactors and with $\mathrm{CO}_{2}$ supplied from SOFC exhaust - to air, in order to use digestate as growing substrate for new biomass, algae, using $\mathrm{CO}_{2}$ as a circular approach inside the biomass considered chain.

\subsection{Nomenclature}

A is the area of the chamber $\left(\mathrm{mm}^{2}\right)$

a is the area of the field of view of the microscope

ATP adenosine triphosphate

B1 dilution 1:20, 20\% inoculum

B2 dilution $1: 50,20 \%$ inoculum

B3 dilution $1: 70,20 \%$ inoculum

B4 dilution $1: 70,9 \%$ inoculum

B5 dilution $1: 70,20 \%$ inoculum

B6 dilution 1:70, 32\% inoculum

$\mathrm{N}^{\circ} \quad$ is the algal counted on the slide

$\mathrm{Ni}$ is the number of the squares counted

R1 dilution $1: 20,0 \%$ inoculum, $\mathrm{CO}_{2}$ addition

SOFC Solid Oxide Fuel Cells

$\mathrm{V} \quad$ was the volume considered

\section{MATERIALS AND METHODS}

The digestate from municipal solid waste was obtained at the end of a biogas production process at FEM (San Michele a/A, Trento). The process is described in detail elsewhere (Papurello et al., 2012). The digestate was collected after 30 days of mesophilic dry anaerobic digestion. The digestate was characterized about $\mathrm{pH}, \mathrm{TS}$ content driyng at $105^{\circ} \mathrm{C}$ and VS content by burining the dry matter obtained at $550^{\circ} \mathrm{C}$. The digestate was sieved at $2 \mathrm{~mm}$ and diluted $(\mathrm{v} / \mathrm{v})$ at different percentage in order to define the best dilution and to avoid turbidity inhibition of microalgae growth. The digestate was than sterilized in an autoclave at $121^{\circ} \mathrm{C}$ for $20 \mathrm{~min}$.

The inoculum was a common green alga; Chlorella vulgaris (strain Chlorella vulgaris K-1801 SCAAP-DK). The microalga was initially grown in algal broth culture medium at $25^{\circ} \mathrm{C}$ with a $14: 10$ light:dark cycle with $50 \mu \mathrm{mol} \mathrm{m} \mathrm{m}^{-2} \mathrm{~s}$ ${ }^{-1}$ measured at the culture surface using a Quantum PhotoRadiometer (Delta Ohm srl, Caselle di Selvazzano, PD, Italy). Algal cells were harvested by gentile centrifugation and washed twice with distilled water before inoculation to insure no nutrient carryover.

$\mathrm{CO}_{2}$ was provided simulating SOFC exhausts completely dried after a condenser section and with no gas pollutants. A representative SOFC generator exhausts was studied elsewhere (Santarelli, Briesemeister, Gandiglio, Herrmann, Kuczynski, Kupecki, Lanzini, Llovell, Papurello, Spliethoff, Swiatkowski, Torres-sanglas, et al., 2017) and now is under investigation for another research work. Carbon dioxide along with liquid water are components that are easily removed. $\mathrm{CO}_{2}$ flow was provided with a Mass Flow Controller (Bronkhorst, The Netherlands) using a gas cylinder (Siad, Italy).

The tests were accomplished with $250 \mathrm{~mL}$ Erlenmeyer flasks. The laboratory scale system was built with a 15-liter volume reactor for verifying the algal growth with $\mathrm{CO}_{2}$ supply $2 \mathrm{~mL} \mathrm{~min}^{-1}$.

Algal growth was tested under conditions listed in Table 1 for defining the digestate dilution (Tests B1-B3), algal inoculum (Tests $\mathrm{B} 4-\mathrm{B} 6$ ) and the $\mathrm{CO}_{2}$ supply (R1).

Digestate dilution is the ratio between 1 moles of digestate and, 20 to 70 moles of water. Microalgal growth was determined by cell concentration. Every three days $0.5 \mathrm{~mL}$ of inoculated digestate was sampled, diluted with $3 \mathrm{~mL}$ of distilled water and fixed with Lugol's solution (SigmaAldrich, Germany). Algal cells were counted with a Fuchs-Rosenthal hemocytometer at $200 \mathrm{X}$ magnification and measured with a calibrated ocular micrometer to determine biovolume. At least 400 cells were counted for each sample and cells were separated into small $(6 \mathrm{~mm})$, medium $(10 \mathrm{~mm})$ and large $(15 \mathrm{~mm})$ cells, measuring 25 cells per size class. Biovolume was calculated according to equation (1) and expressed in $\left(\mathrm{mm}^{3} \mathrm{~mL}^{-1}\right)$. All samples were replicated three times.

$N^{\circ} / m L=N i \times A / a \times 1 / N i \times 1 / V$

Where:

$\mathrm{N}^{\circ}$ is the algal counted on the slide; $\mathrm{A}$ is the area of the chamber $\left(\mathrm{mm}^{2}\right)$; 
$\mathrm{a}$ is the area of the field of view of the microscope; $\mathrm{Ni}$ is the number of the squares counted and $\mathrm{V}$ was the volume considered.

\section{RESULTS AND DISCUSSION}

\subsection{Digestate dilution and microalgal inoculum tests}

Algae growth using digestate (from the anaerobic digestion batch) as the culture medium was analyzed. Preliminarily it was defined the dilution effect, the percent algae inoculum added to the starting batch

The raw digestate have $29.80 \%$ of TS, $17.56 \%$ of VS and $\mathrm{pH}$ 8.54. The digestate dilution effect on TS content was reported in Table 2.

The batch results and the trial description are reported in the Figure 1. The best dilution for the digestate was found to be at 1:70 (B3), giving a cell biovolume of around $11.24 \mathrm{~mm}^{3} \mathrm{~mL}^{-1}$ at the end of the trial (28 days), 79\% and $81 \%$ higher than the dilution of 1:50 (B2) and 1.20 (B1), respectively. Diluting the digestate 30 times instead of five times enhanced the growth of $C$. vulgaris, $C$. sorokiniana and Scenedesmus spp. strains (Zuliani et al., 2016). The highest digestate concentration (dilution 1:20 and 1:50 of raw digestate) gave the lowest algal growth (Figure 1). The high turbidity of the digestate caused by particulate matter is an important issue, although microalgal cultivation can partly reduce the turbidity by removing suspended solids. From our results, the TS concentration of digestate must be less than $4.5 \mathrm{~g} \mathrm{~L}^{-1}$ to avoid turbidity inhibition of microalgal growth and guarantees a sufficient light penetration. Higher values of TS content probably prevent the microalgal growth.

The test (B5) (+20\%) had the highest algae growth with a total production of $25.57\left(\mathrm{~mm}^{3} \mathrm{~mL}^{-1}\right.$ - Figure 2$)$. The high-
TABLE 1: Experimental conditions: digestate dilution is the ratio between digestate and water; algal inoculum is the percentage of microalgae culture added to the digestate for the initial growth; $\mathrm{CO}_{2}$ addition is the condition with or not $\mathrm{CO}_{2}$ and the percentage of loading.

\begin{tabular}{l|c|c|c}
\hline trial & digestate dilution & algal inoculum & $\mathbf{C O}_{2}$ addition \\
\hline B1 & $1: 20$ & $20 \%$ & no \\
\hline B2 & $1: 50$ & $20 \%$ & no \\
\hline B3 & $1: 70$ & $20 \%$ & no \\
\hline B4 & $1: 70$ & $9 \%$ & no \\
\hline B5 & $1: 70$ & $20 \%$ & no \\
\hline B6 & $1: 70$ & $32 \%$ & no \\
\hline R1 & $1: 70$ & $20 \%$ & $350 \mathrm{ppm}(\mathrm{v})$ \\
\hline
\end{tabular}

TABLE 2: Digestate dilution and TS concentration of the different tests.

\begin{tabular}{l|c|c}
\hline trial & digestate dilution & TS content \\
\hline B1 & $1: 20$ & $14.90 \mathrm{~g} \mathrm{~L}-1$ \\
\hline B2 & $1: 50$ & $5.96 \mathrm{~g} \mathrm{~L}-1$ \\
\hline B3-B6 & $1: 70$ & $4.25 \mathrm{~g} \mathrm{~L}-1$ \\
\hline
\end{tabular}

est nominal inoculum condition (B6) and the lowest (B4) inoculum condition had the lowest biovolume ( 9.43 and 19.66 ( $\mathrm{mm}^{3} \mathrm{~mL}^{-1}$, respectively). At the end of the process, B6 showed an increasing trend lower than the nominal case of $20 \%$ (B5). As reported by Uggetti et al. (2014) microalgal growth was positively correlated with the initial inoculum and digestate concentration (Uggetti, Sialve, Latrille, \& Steyer, 2014). Higher initial microalgal concentration produced more biomass. The inoculum size of our tests was about $0.78 \mathrm{~mm}^{3} \mathrm{~mL}^{-1}, 1.18 \mathrm{~mm}^{3} \mathrm{~mL}^{-1}$ and 1.85

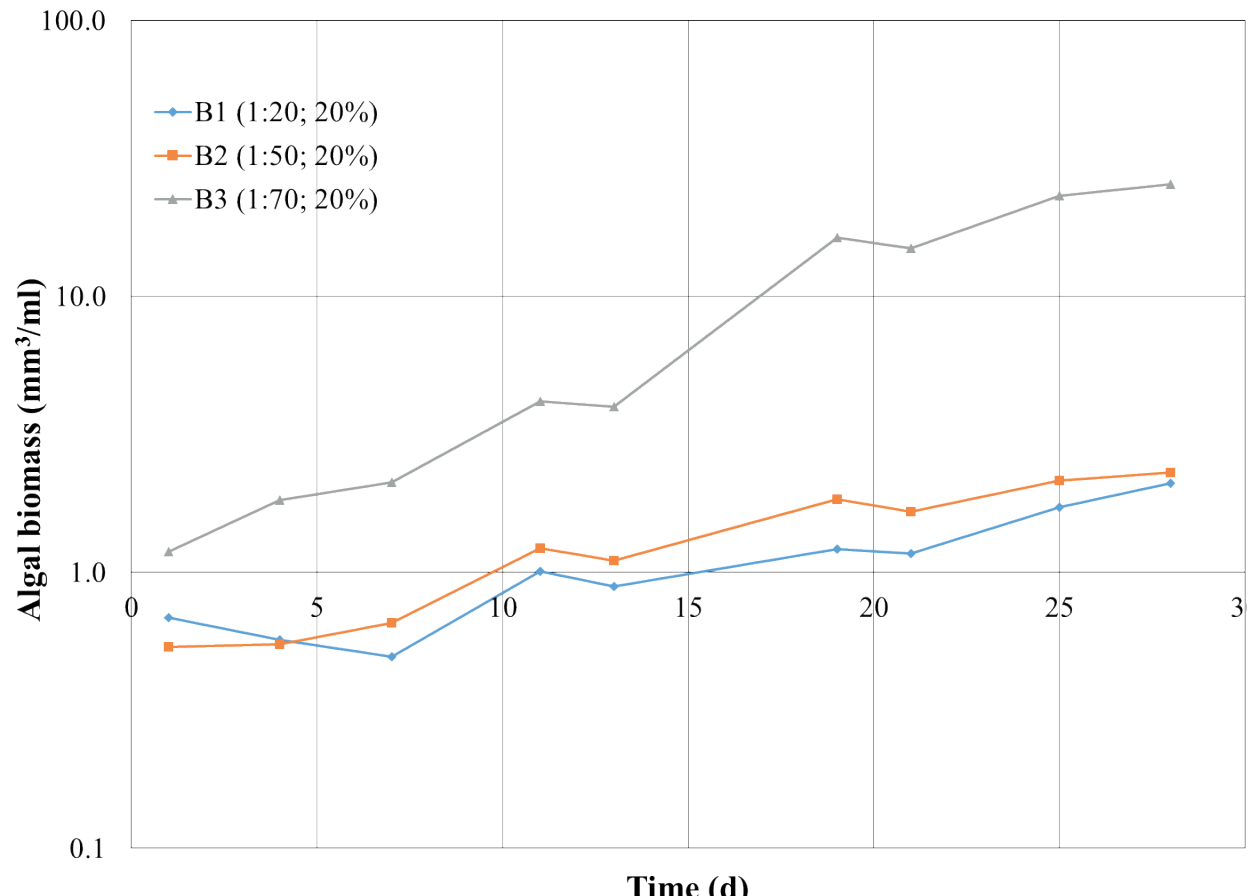

Time (d)

FIGURE 1: Digestate dilution effect $B 1=1: 20, B 2=1: 50, B 3=1: 70$. 


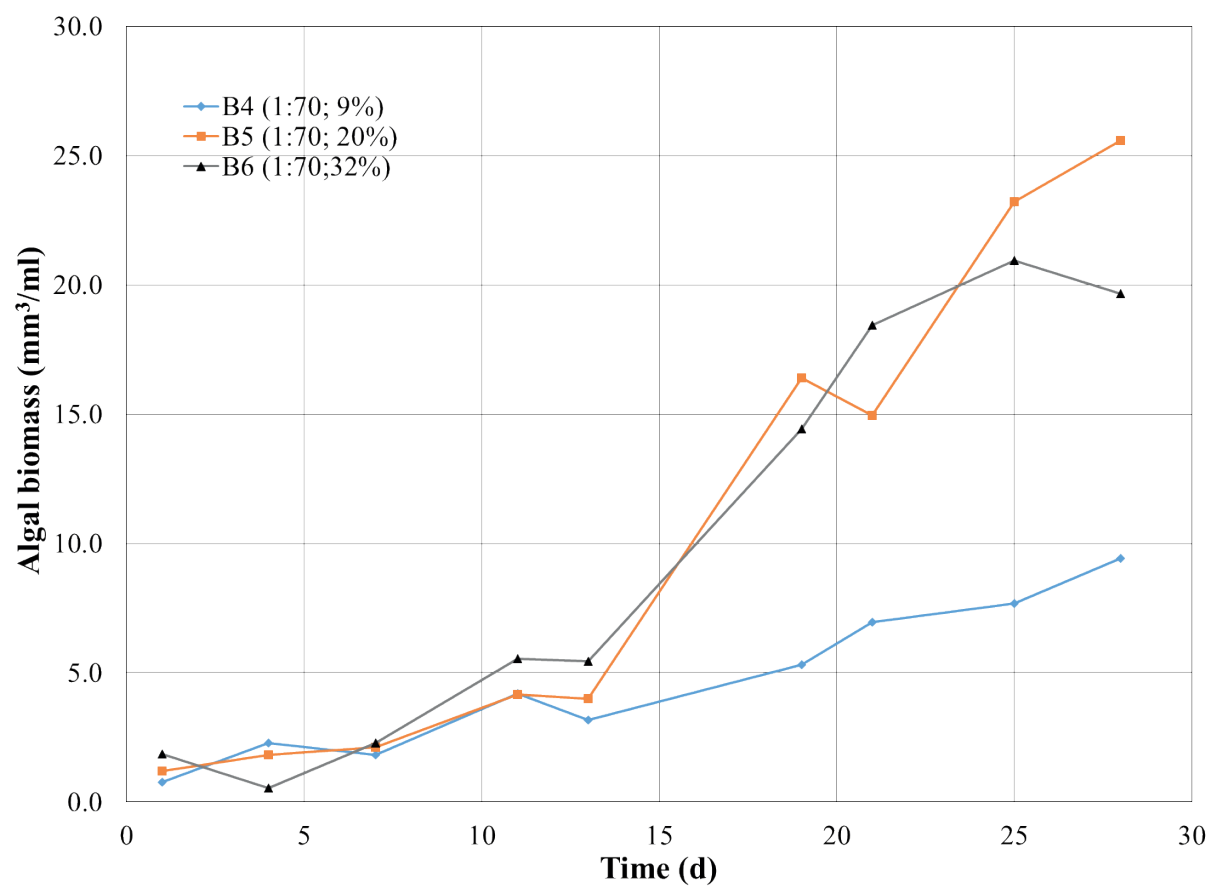

FIGURE 2: Inoculum effect B4=+9\%, B5=+20\%, B6=+32\%.

$\mathrm{mm}^{3} \mathrm{~mL}^{-1}$ for $9 \%, 20 \%$ and $32 \%$ of inoculum size respectively, that correspond at $4.4810 \mathrm{E}^{6}$ cell mL $\mathrm{mL}^{-1}, 1.1010 \mathrm{E}^{7}$ cell $\mathrm{mL}^{-1}$ and $1.8710 \mathrm{E}^{7}$ cell $\mathrm{mL}^{-1}$. In agreement with Lau et al. (1995), (Lau, Tam, \& Wong, 1995) the super concentrated culture of Chlorella vulgaris (with an initial inoculum of $1 \mathrm{E} 107$ cells $\mathrm{mL}^{-1}$ ) did not exhibit any self-shading limitation of growth and nutrient removal.

\subsection{Carbon dioxide supply tests}

Figure 3 shows algal growth for R1, enriched with $\mathrm{CO}_{2}$ (350 ppm (v)) continuously for two months and the digestate was diluted according to the best results identified in the previously trials. The microalgal biovolume was similar to laboratory tests $\left(23.31\left(\mathrm{~mm}^{3} \mathrm{~mL}^{-1}\right)\right.$, comparable with the results of $\mathrm{B} 5$ at the same digestate concentration and inoculum dosage $\left(25.57\left(\mathrm{~mm}^{3} \mathrm{~mL}^{-1}\right)\right.$. The algal growth was different comparing to the preliminary tests on Erlenmeyer flask, highlighting the effect on mixing system and acclimation of the microalgae to anaerobic medium. The microalgal inoculum was prepared using nitrate as main nitrogen source, while in the diluted digestate used as growth medium the ammonia is prevalent. Previous work conducted in similar condition has been demonstrated that the ammonia was preferred $\mathrm{N}$ substrate [24]. Our results confirm this effect, but highlighted that when the medium volume increased a higher lag-phase could occur. This effect suggests that a short acclimation time at aerobic condition of anaerobic diluted digestate with ambient air, could decrease the very long lag phase. Another reason regarded to the mixing system adopted. Increasing the bubbling $\mathrm{CO}_{2}$ mixed to ambient air up to $0.2 \mathrm{vvm}$ will guarantee a better medium blending promoting a better light penetration in agreement with Ryu et al., 2009 (Ryu, Oh, \& Kim, 2009).

$\mathrm{pH}$ was measured during the process to understand why algal production did not increase substantially. R1 showed a low $\mathrm{pH}$ value in the lag phase of microalgal growth compared to B5 (6.2 vs 9.2). The starting pH of R1 reactor was 8.5 and it was acidified following $\mathrm{CO}_{2}$ enrichment. During the logarithmic growth of microalgae, $\mathrm{pH}$ decreased to 7.8 following the $\mathrm{CO}_{2}$ uptake in microalgal cells.

Our results were slightly lower than other studies of microalgae cultivated in liquid digestate (Franchino, Comino, Bona, \& Riggio, 2013; Uggetti et al., 2014; Xia \& Murphy, 2016). The main inhibition phenomena of algal growth were due to the particulate matter content and turbidity, as well as to the color of the starting digestate, despite high dilutions.

\section{CONCLUSIONS}

The best dilution for the digestate was found to be approximately $1: 70$ and inoculum percentage equal to $20 \%$. Algal growth coupled to $\mathrm{CO}_{2}$ fixation by algae was verified experimentally, using the best conditions identified in the laboratory tests. The present work provided preliminary information about algal growth with digestate from dry anaerobic digestion of OFMSW and $\mathrm{CO}_{2}$ from SOFC exhausts. These results will allow performing specific tests with experimental photobioreactors to verify algal productivity, ammonia and phosphate removal efficiency from digestate, $\mathrm{CO}_{2}$ fixation rate and $\mathrm{CO}_{2}$ fixation efficiency. This work is currently underway.

\section{AKNOWLED GEMENTS}

This research is part of the BWS project (Biowaste for SOFCs) carried out with Fondazione Edmund Mach and SOLIDpower SpA. 


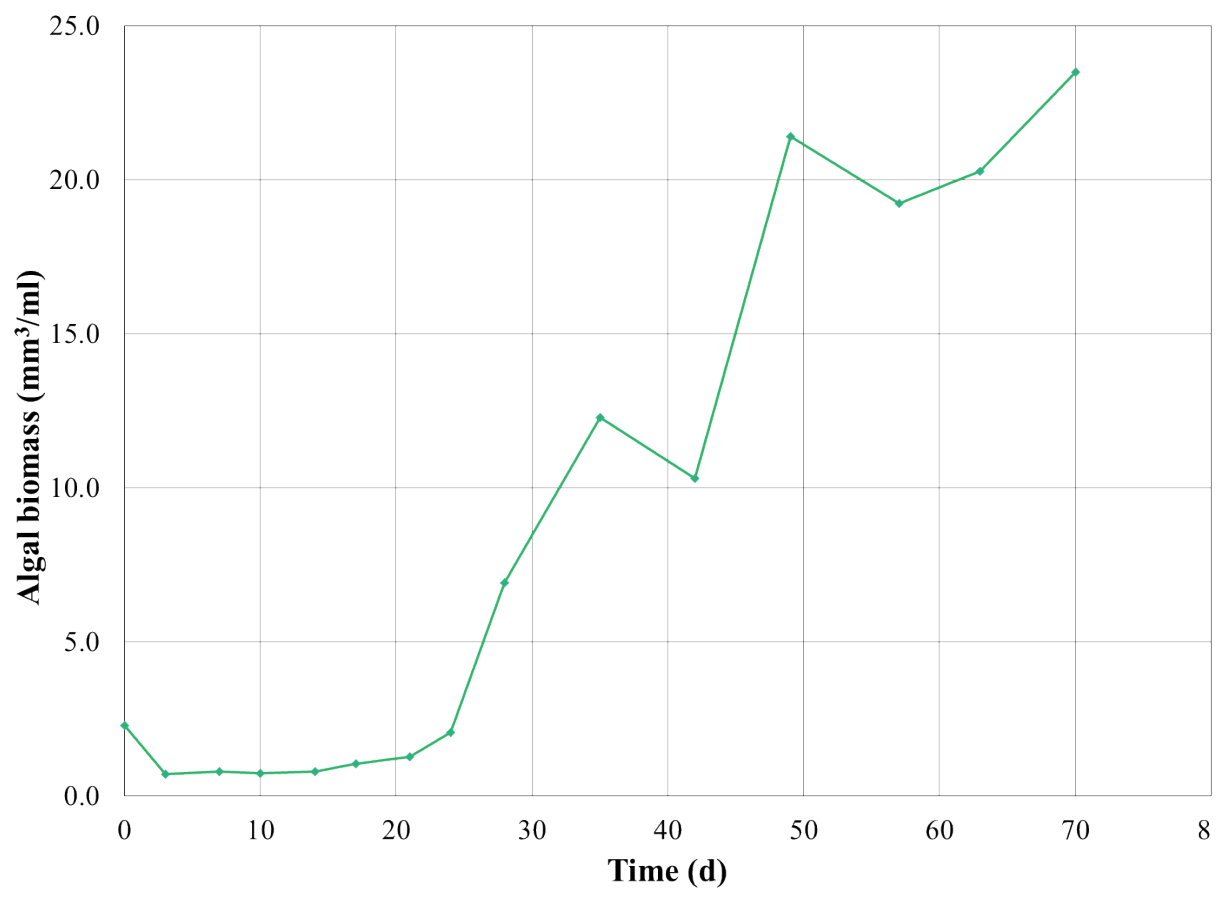

FIGURE 3: Experimental photobioreactor with digestate at 1:70 dilution and $\mathrm{CO}_{2} 350 \mathrm{ppm}(\mathrm{v})$ continuously feeding.

\section{REFERENCES}

Benemann, J. R. (1997). Pergamon, 38(96), 475-479.

Choudhury, A., Chandra, H., \& Arora, a. (2013). Application of solid oxide fuel cell technology for power generation - A review. Renewable and Sustainable Energy Reviews, 20, 430-442. https://doi. org/10.1016/j.rser.2012.11.031

Eveloy, V., \& Gebreegziabher, T. (2019). Excess electricity and powerto-gas storage potential in the future renewable-based power generation sector in the United Arab Emirates. Energy, 166, 426-450. https://doi.org/10.1016/j.energy.2018.10.088

Franchino, M., Comino, E., Bona, F., \& Riggio, V. A. (2013). Growth of three microalgae strains and nutrient removal from an agro-zootechnical digestate. Chemosphere, 92(6), 738-744. https://doi. org/10.1016/j.chemosphere.2013.04.023

Hagen, A., Rasmussen, J. F. B., \& Thydén, K. (2011). Durability of solid oxide fuel cells using sulfur containing fuels. Journal of Power Sources, 196(17), 7271-7276. https://doi.org/10.1016/j.jpowsour.2011.02.053

Ho, S., Kondo, A., Hasunuma, T., \& Chang, J. (2013). Engineering strategies for improving the $\mathrm{CO} 2$ fixation and carbohydrate productivity of Scenedesmus obliquus CNW-N used for bioethanol fermentation. Bioresource Technology, 143, 163-171. https://doi. org/10.1016/j.biortech.2013.05.043

Kupecki, J., Kluczowski, R., Papurello, D., Lanzini, A., Kawalec, M., Krauz, M., \& Santarelli, M. (2018). Characterization of a circular $80 \mathrm{~mm}$ anode supported solid oxide fuel cell (AS-SOFC) with anode support produced using high-pressure injection molding (HPIM). International Journal of Hydrogen Energy. https://doi.org/10.1016/j. ijhydene.2018.02.143

Lanzini, A., Ferrero, D., Papurello, D., \& Santarelli, M. (2017). Reporting Degradation from Different Fuel Contaminants in Ni-anode SOFCs. Fuel Cells, 17(4). https://doi.org/10.1002/fuce.201600184

Lanzini, A., Leone, P., \& Asinari, P. (2009). Microstructural characterization of SOFC electrodes by image analysis technique. Elsevier.

Lau, P. S., Tam, N. F. Y., \& Wong, Y. S. (1995). Effect of algal density on nutrient removal from primary settled wastewater. Environmental Pollution, 89, 59-66. https://doi.org/10.1155/2015/739147

Molino, a., Nanna, F. Ding, Y, Bikson, B. \& Braccio, G. (2013). Biomethane production by anaerobic digestion of organic waste. Fuel, 103 1003-1009. https://doi.org/10.1016/j.fuel.2012.07.070

Packer, M. (2009). Algal capture of carbon dioxide ; biomass generation as a tool for greenhouse gas mitigation with reference to New Zealand energy strategy and policy. Energy Policy, 37(9), 34283437. https://doi.org/10.1016/j.enpol.2008.12.025
Papurello, D. lafrate, C , Lanzini, A \& Santarelli, M. (2017). Trace compounds impact on SOFC performance: Experimental and modelling approach. Applied Energy, 208. https://doi.org/10.1016/j.apenergy.2017.09.090

Papurello, D., \& Lanzini, A. (2017). SOFC single cells fed by biogas: Experimental tests with trace contaminants. Waste Management. https://doi.org/10.1016/j.wasman.2017.11.030

Papurello, D., Lanzini, A., Leone, P., \& Santarelli, M. (2016). The effect of heavy tars (toluene and naphthalene) on the electrochemical performance of an anode-supported SOFC running on bio-syngas. Renewable Energy, 99, 747-753. https://doi.org/10.1016/j. renene.2016.07.029

Papurello, D., Lanzini, A., Tognana, L., Silvestri, S., \& Santarelli, M. (2015). Waste to energy: Exploitation of biogas from organic waste in a 500 Wel solid oxide fuel cell (SOFC) stack. Energy, 85, 145-158. https://doi.org/10.1016/j.energy.2015.03.093

Papurello, D., Menichini, D., \& Lanzini, A. (2017). Distributed relaxation times technique for the determination of fuel cell losses with an equivalent circuit model to identify physicochemical processes. Electrochimica Acta, 258, 98-109. https://doi.org/10.1016/j.electacta.2017.10.052

Papurello, D., Schuhfried, E., Lanzini, A., Romano, A., Cappellin, L., Märk, T. D., ... Biasioli, F. (2015). Proton transfer reaction-mass spectrometry as a rapid inline tool for filter efficiency of activated charcoal in support of the development of Solid Oxide Fuel Cells fueled with biogas. Fuel Processing Technology, 130(C). https:// doi.org/10.1016/j.fuproc.2014.09.042

Papurello, D., Silvestri, S., Tomasi, L., Belcari, I., Biasioli, F., \& Santarelli, M. (2016a). Biowaste for SOFCs. In Energy Procedia (Vol. 101). https://doi.org/10.1016/j.egypro.2016.11.054

Papurello, D., Silvestri, S., Tomasi, L., Belcari, I., Biasioli, F., \& Santarelli, M. (2016b). Natural Gas Trace Compounds Analysis with Innovative Systems: PTR-ToF-MS and FASTGC. In Energy Procedia (Vol. 101). https://doi.org/10.1016/j.egypro.2016.11.068

Papurello, D., Soukoulis, C., Schuhfried, E., Cappellin, L., Gasperi, F., Silvestri, S., ... Biasioli, F. (2012). Monitoring of volatile compound emissions during dry anaerobic digestion of the Organic Fraction of Municipal Solid Waste by Proton Transfer Reaction Time-ofFlight Mass Spectrometry. Bioresource Technology, 126. https:// doi.org/10.1016/j.biortech.2012.09.033

Papurello, D., Tognana, L., Lanzini, A., Smeacetto, F., Santarelli, M., Belcari, I., ... Biasioli, F. (2015). Proton transfer reaction mass spectrometry technique for the monitoring of volatile sulfur compounds in a fuel cell quality clean-up system. Fuel Processing Technology, 130(C). https://doi.org/10.1016/j.fuproc.2014.09.041 
Papurello, D., Tomasi, L., \& Silvestri, S. (2018). Proton transfer reaction mass spectrometry for the gas cleaning using commercial and waste-derived materials: Focus on the siloxane removal for SOFC applications. International Journal of Mass Spectrometry, 430. https://doi.org/10.1016/j.jims.2018.05.002

Papurello, D., Tomasi, L., Silvestri, S., Belcari, I., Santarelli, M., Smeacetto, F., \& Biasioli, F. (2016). Biogas trace compound removal with ashes using proton transfer reaction time-of-flight mass spectrometry as innovative detection tool. Fuel Processing Technology, 145, 62-75. https://doi.org/10.1016/j.fuproc.2016.01.028

Papurello, D., Tomasi, L., Silvestri, S., \& Santarelli, M. (2016). Evaluation of the Wheeler-Jonas parameters for biogas trace compounds removal with activated carbons. Fuel Processing Technology, 152. https://doi.org/10.1016/j.fuproc.2016.06.006

Rasi, S. (2009). Biogas Composition and Upgrading to Biomethane Saija Rasi Biogas Composition and Upgrading to Biomethane. https:// doi.org/978-951-39-3607-5

Rosenberg, J. N., Mathias, A., Korth, K., Betenbaugh, M. J., \& Oyler, G. A. (2011). Microalgal biomass production and carbon dioxide sequestration from an integrated ethanol biorefinery in lowa : A technical appraisal and economic feasibility evaluation. Biomass and Bioenergy, 35(9), 3865-3876. https://doi.org/10.1016/j.biombioe.2011.05.014

Ryu, H. J., Oh, K. K., \& Kim, Y. S. (2009). Optimization of the influential factors for the improvement of $\mathrm{CO} 2$ utilization efficiency and $\mathrm{CO} 2$ mass transfer rate. Journal of Industrial and Engineering Chemistry, 15(4), 471-475. https://doi.org/10.1016/j.jiec.2008.12.012

Saadabadi, S. A., Thallam, A., Fan, L., Lindeboom, R. E. F., Spanjers, H., \& Aravind, P. V. (2019). Solid Oxide Fuel Cells Fuelled with Biogas : Potential and Constraints. Renewable Energy, 134, 1-26. https:// doi.org/10.1016/j.renene.2018.11.028
Santarelli, M., Briesemeister, L., Gandiglio, M., Herrmann, S., Kuczynski, P., Kupecki, J., ... Vega, L. F. (2017). Carbon recovery and re-utilization ( CRR ) from the exhaust of a solid oxide fuel cell ( SOFC): Analysis through a proof-of-concept. Biochemical Pharmacology, 18, 206-221. https://doi.org/10.1016/j.jcou.2017.01.014

Santarelli, M., Briesemeister, L., Gandiglio, M., Herrmann, S., Kuczynski, P., Kupecki, J., ... Vega, L. F. (2017). Carbon recovery and re-utilization (CRR) from the exhaust of a solid oxide fuel cell (SOFC): Analysis through a proof-of-concept. Journal of CO2 Utilization, 18. https://doi.org/10.1016/j.jcou.2017.01.014

Shiratori, Y., Ijichi, T., Oshima, T., \& Sasaki, K. (2010). Internal reforming SOFC running on biogas. International Journal of Hydrogen Energy, 35(15), 7905-7912. https://doi.org/10.1016/j. ijhydene.2010.05.064

Strange, K., Hastings, P. M., \& Wales, N. S. (2010). Enhancing participation in kitchen waste collections : International review of overseas experience. In Defra Waste \& Resources Evidence Programme WR0209.

Uggetti, E., Sialve, B., Latrille, E., \& Steyer, J. P. (2014). Anaerobic digestate as substrate for microalgae culture: The role of ammonium concentration on the microalgae productivity. Bioresource Technology, 152, 437-443. https://doi.org/10.1016/j. biortech.2013.11.036

Xia, A., \& Murphy, J. D. (2016). Microalgal Cultivation in Treating Liquid Digestate from Biogas Systems. Trends in Biotechnology, 34(4), 264-275. https://doi.org/10.1016/j.tibtech.2015.12.010

Zuliani, L., Frison, N., Jelic, A., Fatone, F., Bolzonella, D., \& Ballottari, M (2016). Microalgae Cultivation on Anaerobic Digestate of Municipal Wastewater, Sewage Sludge and Agro-Waste. https://doi. org/10.3390/ijms17101692 